\title{
Structure and Tree Diversity in a Mixed Ombrophilous Forest Remnant, Southern Brazil
}

\author{
Manuela Gazzoni dos Passos ${ }^{1}$ \\ Geisa Percio do Prado ${ }^{1}$ \\ Cláudia Fontana ${ }^{2}$ \\ Edmilson Bianchini ${ }^{1}$
}

\begin{abstract}
This study aimed to determine the tree structure, floristic composition and species diversity in the Araucaria State Park, southern Brazil. We allocated 100 plots of $100 \mathrm{~m}^{2}(1 \mathrm{ha})$ each one, and we recorded all trees with diameters at breast height $\geq 5 \mathrm{~cm}$. We sampled 1368 individuals of 106 species, 75 genera and 44 families. Fabaceae, Lauraceae and Myrtaceae showed the greatest richness of species. The diversity of tree species was high $\left(\mathrm{H}^{\prime}=3.96\right)$, although the observed richness was less than the estimated one. The basal area was $46.88 \mathrm{~m}^{2}$ ha $^{-1}$. We observed an intrinsic association between Araucaria angustifolia and Nectandra megapotamica, and a predominance of secondary and zoochorous (> 70\%) species. Endangered and vulnerable species in the Santa Catarina state, such as Araucaria angustifolia, Cedrela fissilis, Dicksonia sellowiana and Ocotea porosa were sampled in the Park, highlighting its importance for the conservation of the Mixed Ombrophylous Forest.
\end{abstract}

Keywords: araucaria, conservation unit, floristic, forest remnant, phytosociology.

\section{INTRODUCTION AND OBJECTIVES}

The Mixed Ombrophylous Forest (MOF), also called Araucaria Forest, is predominantly distributed in southern Brazil, with small patches in southeastern Brazil, in the far northeast of Argentina and east of Paraguay (IBGE, 2012; Klein, 1960). In Santa Catarina state (SC), this forest originally occupied 45\% of the total area covered by natural forests (Vibrans et al., 2013). However, since the end of the 19th century, the area of MOF has been reduced by anthropic action such as firewood for domestic purposes, timber industry, agribusiness, and urbanization (Carvalho, 2012; Rondon Neto et al., 2002a; Sevegnani et al., 2012). Currently, MOF is highly reduced and fragmented (Shaw, 2019) to about $25 \%$ of the original area of MOF remaining in SC (Vibrans et al., 2013). Part of these MOF areas are protected in Conservation Units (UC).

Despite the ecological, economic and cultural importance of MOF for the state of SC, there are still great gaps in the knowledge of its composition and structure. Some studies in floristics and phytosociology were developed for the northern plateau of state (Formento et al., 2004; Gasper et al., 2013a,b; Herrera et al. 2009; Lingner et al., 2007; Negrelle \& Silva, 1992) and there has recently been an important increase in such knowledge for the southern plateau of state (Dallabrida et al., 2018; Higuchi et al., 2013; Klauberg et al., 2010; Manfredi et al., 2015; Martins et al., 2012; Santos et al., 2018; Silva et al., 2016). In a review of phytosociological studies in MOF for southern Brazil, we found no studies for the western region of SC. Data from this region is available only from the systematic survey of the Forest Floristic Inventory of Santa Catarina (IFFSC) (Gasper et al., 2013a,b). In IFFSC survey, 0.4 ha plots were set $10 \mathrm{~km}$ apart one from another, where all trees with diameter at breast height $(\mathrm{DBH}) \geq 10 \mathrm{~cm}$ were sampled (Vibrans et al., 2010). We also highlight the pioneering study on SC flora carried out by Roberto Miguel Klein and Fr. Raulino Reitz. These studies resulted in the publication of Flora Illustrated Catarinense, which greatly contributed to the floristic knowledge of the western region (Klein, 1960, 1978; Reitz, 1965). Even so, there is a gap in the floristic, phytosociological, and structural knowledge of the MOF for the western region of SC.

${ }^{1}$ Universidade Estadual de Londrina, Centro de Ciências Biológicas, Londrina, PR, Brasil

${ }^{2}$ Universidade de São Paulo, Escola Superior de Agricultura “Luiz de Queiroz”, Piracicaba, SP, Brasil 
In accord to Klein (1960), MOF presents distinct floristic associations in southern Brazil. For this reason, local and regional knowledge of biodiversity is essential, as it allows the identification of stenotopic species, which are unable to tolerate drastic changes in the environment, occupy specific ecological niches, and have a restricted geographical distribution (Dajoz, 1983). Therefore, regional floristic knowledge is essential both for the conservation of these associations and for subsidising projects for the restoration of degraded areas according to the regional composition. We must highlight that the MOF in western SC is neighboring the Seasonal Deciduous Forest, which makes the flora of this region very peculiar (Klein, 1978).

The Araucaria State Park (PEAR) with an area of 612 ha is one of the last MOF conserved remnants in western SC (FATMA, 2015). PEAR is subject to high anthropic pressure, because it is immersed in an agricultural matrix that reduces connectivity with other fragments. The New Brazilian Forest Code (Brazil, 2012) determines the forest restoration of areas of permanent preservation and legal reserve, which are essential for the formation of ecological corridors. Connecting the MOF fragments is important for maintaining the biological and genetic diversity of populations. In addition, Brazil committed to restoring and reforesting 12 million hectares of forests by 2030 in the Paris Agreement (FGV, 2018). In this context, the study on getting to know about structure and floristic composition at the local and regional level is urgent and plays an important role as a source of information to support for forest restoration projects.

This study aimed to characterise the structure, tree floristic composition, and tree species diversity of PEAR. Its results can serve as a reference for the region's floristic structure and composition, subsidising environmental restoration projects.

\section{MATERIALS AND METHODS}

\subsection{Study area}

The Araucaria State Park - PEAR (26 $27^{\prime} 08^{\prime \prime}$ S and 52 $\left.33^{\prime} 56^{\prime \prime} \mathrm{W}\right)$ is located in the municipalities of São Domingos and Galvão, western SC (Figure 1). Before the establishment of PEAR in May 2003, part of the area was used for the extraction and processing of wood, especially Araucaria angustifolia (Bertol.) Kuntze (FATMA, 2015). Until May 2003, some areas had not been explored, and others were in the process of regeneration. Therefore, the PEAR landscape is made up of forest patches in different successional stages.

According to the Köppen classification, the region's climate is of the Cfb type - with mild summers (Alvares et al., 2013). Temperatures in the coldest month range from $-3^{\circ} \mathrm{C}$ to $18^{\circ} \mathrm{C}$, and temperatures in the hottest month are over $22^{\circ} \mathrm{C}$. The average annual precipitation is approximately $2,400 \mathrm{~mm}$ (Santa Catarina, 1986).
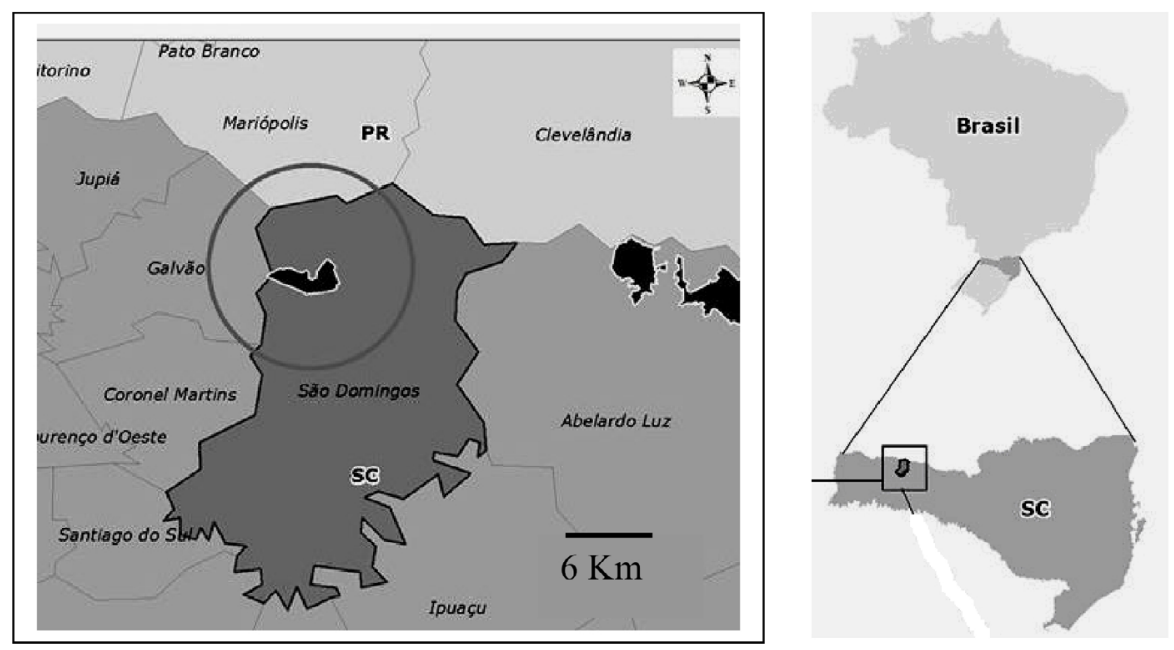

Figure 1. Location of Parque Estadual das Araucárias, western Santa Catarina (SC), southern Brazil.

\subsection{Sampling and data analysis}

On a PEAR map we systematically allocated 100 plots of $100 \mathrm{~m}^{2}(10 \mathrm{~m} \times 10 \mathrm{~m})$ totaling 1 ha, seeking to represent all areas of the PEAR, but avoiding those that are difficult to access or particularly degraded. These plots were later demarcated in the field. We sampled all tree individuals with $\mathrm{DBH} \geq 5$ $\mathrm{cm}$. The identification of plants was carried out in the field or after collection and herborisation by consulting herbarium collections, the literature's bibliography, and specialists. 
The list of species was grouped by family according to the APG IV system (APG, 2016), and the name of the species and their authorship are in agreement with "Flora do Brasil" (http://floradobrasil.jbrj.gov.br).

The rarefaction curve was calculated in order to compare the observed richness to the estimated richness by the Jackknife2 method, using the EstimateS 9.1.0 software (Colwell, 2013) with 100 randomisations of the sample order and a $95 \%$ confidence interval. In accord to Oliveira et al. (2016), Jackknife2 is the best diversity estimator for SC forests.

We calculated density, dominance, frequency (absolute and relative), Importance Value Index (Mueller-Dombois \& Ellenberg, 1974) and Shannon's diversity and Pielou's equability indices (Ludwig \& Reynolds, 1988) in the Mata Nativa 2 software (Cientec, 2006).

The sampled individuals were grouped into seven classes of diameter: $5 \mathrm{~cm} \leq 10 \mathrm{~cm} ;>10 \mathrm{~cm} \leq 20 \mathrm{~cm} ;>20 \mathrm{~cm} \leq 30 \mathrm{~cm}$; $>30 \mathrm{~cm} \leq 40 \mathrm{~cm} ;>40 \mathrm{~cm} \leq 50 \mathrm{~cm} ;>50 \mathrm{~cm} \leq 60 \mathrm{~cm} ;>60$. Additionally, the species were classified into successional categories (pioneer, secondary and climax) according to Backes \& Irgang (2002), Carvalho (2006), Lorenzi (2008) and Meyer et al. (2013) and as for the dispersal syndrome (zoochorous, anemochorous and autochorous), according to Van der Pijl (1982).

\section{RESULTS AND DISCUSSION}

We sampled 1368 individuals from 106 species, distributed in 75 genera and 44 families (Table 1). In 1 ha of MOF in the southern plateau of SC, Higuchi et al. (2013) sampled 1395 individuals of 50 species, 33 genera and 20 families. Herrera et al. (2009) analysed 2.6 ha in the northern plateau of SC, but with inclusion criteria for $\mathrm{DBH} \geq 10 \mathrm{~cm}$, sampling 71 species, distributed in 54 genera and 33 families. Therefore, this study showed the high diversity of tree species in the PEAR, resulting from the different successional stages present in the area.

The analysis of the rarefaction curve has showed that the observed richness was less than the richness estimated by the Jackknife2 estimator, indicating that the species richness may be greater than that sampled (Figure 2). Higuchi et al. (2013) also have recorded observed richness lower than the estimated richness in MOF remnant in the southern plateau of Santa Catarina, using the same estimator. According to the authors, the high floristic diversity of the studied fragment, due to the presence of several patches in different successional stages, caused this difference in richness, similar to the present study.

Table 1. Families and tree species sampled in the Parque Estadual das Araucárias, Santa Catarina, southern Brazil. AD: absolute density; $\mathrm{SC}=$ successional category $(\mathrm{P}=$ pioneer, $\mathrm{S}=$ secondary, $\mathrm{C}=$ climax $) ; \mathrm{LF}=$ life form $(\mathrm{T}=$ tree, $\mathrm{ST}=$ small tree, $\mathrm{TF}=$ tree fern, $\mathrm{SH}=\operatorname{shrub}$, $\mathrm{P}=$ palm tree) (in accord with VIBRANS et al., 2013); $\mathrm{DS}=$ dispersal syndrome $(\mathrm{Z}=$ zoochory, $\mathrm{A}=$ anemochory, $\mathrm{Au}=$ autochory).

\begin{tabular}{|c|c|c|c|c|c|}
\hline Families & Species & AD & SC & LF & DS \\
\hline \multirow[t]{2}{*}{ Anacardiaceae } & Lithraea brasiliensis Marchand & 2 & $\mathrm{P}$ & ST & $\mathrm{Z}$ \\
\hline & Schinus terebinthifolius Raddi & 2 & S & ST & $\mathrm{Z}$ \\
\hline \multirow[t]{2}{*}{ Annonaceae } & Annona neosalicifolia H.Rainer & 5 & $\mathrm{P}$ & $\mathrm{T}$ & $\mathrm{Z}$ \\
\hline & Annona rugulosa (Schltdl.) H.Rainer & 12 & $\mathrm{P}$ & $\mathrm{T}$ & $\mathrm{Z}$ \\
\hline \multirow[t]{3}{*}{ Aquifoliaceae } & Ilex brevicuspis Reissek & 12 & S & ST & $\mathrm{Z}$ \\
\hline & Ilex paraguariensis A. St.-Hil. & 61 & $\mathrm{P}$ & ST & $\mathrm{Z}$ \\
\hline & Ilex theezans Mart. ex Reissek & 2 & $\mathrm{~S}$ & $\mathrm{~T}$ & $\mathrm{Z}$ \\
\hline Araliaceae & Schefflera morototoni (Aubl.) Maguire, Steyerm. \& Frodin & 2 & S & $\mathrm{T}$ & $\mathrm{Z}$ \\
\hline Araucariaceae & Araucaria angustifolia (Bertol.) Kuntze & 31 & $\mathrm{P}$ & $\mathrm{T}$ & $\mathrm{Z}$ \\
\hline Arecaceae & Syagrus romanzoffiana (Cham.) Glassman & 16 & $\mathrm{P}$ & $\mathrm{P}$ & $\mathrm{Z}$ \\
\hline Asparagaceae & Cordyline spectabilis Kunth \& Bouché & 20 & S & ST & $\mathrm{Z}$ \\
\hline Asteraceae & Vernonanthura discolor (Spreng.) H.Rob. & 2 & S & $\mathrm{T}$ & A \\
\hline \multirow[t]{2}{*}{ Bignoniaceae } & Jacaranda micrantha Cham. & 9 & S & $\mathrm{T}$ & A \\
\hline & Jacaranda puberula Cham. & 6 & $\mathrm{~S}$ & ST & A \\
\hline \multirow[t]{3}{*}{ Boraginaceae } & Cordia americana (L.) Gottschling \& J.E.Mill. & 12 & $\mathrm{C}$ & $\mathrm{T}$ & A \\
\hline & Cordia ecalyculata Vell. & 1 & S & $\mathrm{T}$ & A \\
\hline & Cordia trichotoma (Vell.) Arráb. ex Steud. & 2 & $\mathrm{P}$ & $\mathrm{T}$ & A \\
\hline Cannabaceae & Celtis iguanaea (Jacq.) Sarg. & 10 & $\mathrm{P}$ & ST & $\mathrm{Z}$ \\
\hline Cardiopteridaceae & Citronella paniculata (Mart.) R.A.Howard & 2 & - & $\mathrm{T}$ & $\mathrm{Z}$ \\
\hline
\end{tabular}


Table 1. Continued...

\begin{tabular}{|c|c|c|c|c|c|}
\hline Families & Species & AD & SC & LF & DS \\
\hline Celastraceae & Maytenus aquifolia Mart. & 1 & - & $\mathrm{T}$ & $\mathrm{Z}$ \\
\hline Clethraceae & Clethra scabra Pers. & 8 & S & ST & A \\
\hline Cunoniaceae & Lamanonia ternata Vell. & 2 & S & $\mathrm{T}$ & A \\
\hline Cyatheaceae & Alsophila setosa Kaulf. & 55 & $\mathrm{C}$ & TF & A \\
\hline Dicksoniaceae & Dicksonia sellowiana Hook. & 57 & $\mathrm{C}$ & $\mathrm{TF}$ & A \\
\hline Erytroxylaceae & Erythroxylum deciduum A.St.-Hil. & 3 & $\mathrm{~S}$ & ST & $\mathrm{Z}$ \\
\hline \multirow[t]{3}{*}{ Euphorbiaceae } & Actinostemon concolor (Spreng.) Müll.Arg. & 8 & $\mathrm{C}$ & ST & $\mathrm{Au}$ \\
\hline & Sapium glandulosum (L.) Morong & 4 & $\mathrm{P}$ & $\mathrm{T}$ & $\mathrm{Z}$ \\
\hline & Sebastiania commersoniana (Baill.) L.B.Sm. \& Downs & 13 & $\mathrm{P}$ & ST & $\mathrm{Au}$ \\
\hline \multirow[t]{14}{*}{ Fabaceae } & Albizia niopoides (Spruce ex Benth.) Burkart & 7 & $\mathrm{P}$ & $\mathrm{T}$ & A \\
\hline & Apuleia leiocarpa (Vogel) J.F.Macbr. & 3 & $\mathrm{P}$ & $\mathrm{T}$ & A \\
\hline & Ateleia glazioveana Baill. & 65 & $\mathrm{P}$ & $\mathrm{T}$ & A \\
\hline & Dalbergia frutescens (Vell.) Britton & 1 & S & ST & A \\
\hline & Erythrina falcata Benth. & 1 & S & ST & A \\
\hline & Inga virescens Benth. & 3 & S & $\mathrm{T}$ & $\mathrm{Z}$ \\
\hline & $\begin{array}{l}\text { Muellera campestris (Mart. ex Benth.) M.J. Silva \& A.M.G. } \\
\text { Azevedo. }\end{array}$ & 7 & S & $\mathrm{T}$ & A \\
\hline & Lonchocarpus nitidus (Vogel) Benth. & 2 & $\mathrm{P}$ & ST & A \\
\hline & Machaerium paraguariense Hassl. & 3 & S & $\mathrm{T}$ & A \\
\hline & Machaerium stipitatum (DC) Vogel & 12 & S & $\mathrm{T}$ & A \\
\hline & Mimosa scabrela Benth. & 22 & S & $\mathrm{T}$ & A \\
\hline & Myrocarpus frondosus Allemao & 6 & S & $\mathrm{T}$ & A \\
\hline & Parapiptadenia rigida (Benth.) Brenan. & 25 & S & $\mathrm{T}$ & A \\
\hline & Peltophorum dubium (Spreng.) Taub & 1 & $\mathrm{P}$ & $\mathrm{T}$ & A \\
\hline \multirow[t]{8}{*}{ Lauraceae } & Cinnamomum amoenum (Ness \& Mart.) Kosterm. & 14 & S & $\mathrm{T}$ & $\mathrm{Z}$ \\
\hline & Nectandra grandiflora Ness & 36 & S & $\mathrm{T}$ & $\mathrm{Z}$ \\
\hline & Nectandra lanceolata Nees & 7 & S & $\mathrm{T}$ & $\mathrm{Z}$ \\
\hline & Nectandra megapotamica (Spreng.) Mez & 95 & S & $\mathrm{T}$ & $\mathrm{Z}$ \\
\hline & Ocotea diospyrifolia (Meisn.) Mez & 56 & $\mathrm{C}$ & $\mathrm{T}$ & $\mathrm{Z}$ \\
\hline & Ocotea puberula (Rich.) Nees & 53 & $\mathrm{P}$ & $\mathrm{T}$ & $\mathrm{Z}$ \\
\hline & Ocotea pulchella (Ness \& Mart.) Mez & 4 & $\mathrm{P}$ & $\mathrm{T}$ & $\mathrm{Z}$ \\
\hline & Ocotea porosa (Nees \& Mart.) Barroso & 4 & S & $\mathrm{T}$ & $\mathrm{Z}$ \\
\hline Loganiaceae & Strychnos brasiliensis Mart. & 2 & S & $\mathrm{T}$ & $\mathrm{Z}$ \\
\hline Malvaceae & Luehea divaricata Mart. & 59 & S & $\mathrm{T}$ & A \\
\hline \multirow[t]{7}{*}{ Meliaceae } & Cabralea canjerana (Vell.) & 5 & S & $\mathrm{T}$ & $\mathrm{Z}$ \\
\hline & Cedrela fissilis Vell. & 18 & S & $\mathrm{T}$ & A \\
\hline & Cedrela lilloi C. DC. & 1 & S & - & A \\
\hline & Cedrela odorata $\mathrm{L}$. & 4 & S & - & A \\
\hline & Trichilia catigua A. Juss & 1 & $\mathrm{C}$ & ST & $\mathrm{Z}$ \\
\hline & Trichilia clausseni C. DC. & 12 & $S$ & ST & $\mathrm{Z}$ \\
\hline & Trichilia elegans A. Juss & 16 & $S$ & ST & $\mathrm{Z}$ \\
\hline \multirow[t]{2}{*}{ Moraceae } & Ficus luschnathiana (Miq.) Miq. & 2 & $\mathrm{~S}$ & $\mathrm{~T}$ & $\mathrm{Z}$ \\
\hline & Sorocea bonplandii (Bail.) W.C.Burger, Lanj. \& de Boer & 9 & S & ST & $\mathrm{Z}$ \\
\hline
\end{tabular}


Table 1. Continued...

\begin{tabular}{|c|c|c|c|c|c|}
\hline Families & Species & AD & SC & LF & DS \\
\hline \multirow[t]{8}{*}{ Myrtaceae } & Campomanesia guazumifolia (Cambess.) O.Berg & 3 & S & ST & $\mathrm{Z}$ \\
\hline & Campomanesia xanthocarpa (Mart.) O.Berg & 12 & S & $\mathrm{T}$ & $\mathrm{Z}$ \\
\hline & Eugenia involucrata DC. & 2 & S & $\mathrm{T}$ & $\mathrm{Z}$ \\
\hline & Eugenia ramboi D. Legrand & 1 & S & $\mathrm{T}$ & $\mathrm{Z}$ \\
\hline & Eugenia uniflora L. & 3 & S & ST & $\mathrm{Z}$ \\
\hline & Eugenia uruguayensis Cambess. & 1 & $\mathrm{C}$ & ST & $\mathrm{Z}$ \\
\hline & Myrcia oblongata DC. & 11 & $\mathrm{P}$ & ST & $\mathrm{Z}$ \\
\hline & Myrcianthes gigantea (D. Legrand). D. Legrand & 2 & S & $\mathrm{T}$ & $\mathrm{Z}$ \\
\hline Oleaceae & Chionanthus trichotomus (Vell.) P.S.Green & 1 & $\mathrm{C}$ & $\mathrm{T}$ & $\mathrm{Z}$ \\
\hline Phytolaccaceae & Phytolacca dioica $\mathrm{L}$. & 2 & S & $\mathrm{T}$ & $\mathrm{Au}$ \\
\hline Polygoniaceae & Ruprechtia laxiflora Meisn. & 5 & S & $\mathrm{T}$ & A \\
\hline \multirow[t]{3}{*}{ Primulaceae } & Myrsine coriacea (Sw.) R.Br. ex Roem. \& Schult. & 13 & $\mathrm{P}$ & $\mathrm{T}$ & $\mathrm{Z}$ \\
\hline & Myrsine loefgrenii (Mez) Imkhan. & 4 & S & ST & $\mathrm{Z}$ \\
\hline & Myrsine umbellata Mart. & 4 & S & ST & $\mathrm{Z}$ \\
\hline Rhamnaceae & Hovenia dulcis Thunb. & 2 & $\mathrm{P}$ & $\mathrm{T}$ & $\mathrm{Z}$ \\
\hline Rosaceae & Prunus myrtifolia (L.) Urb. & 31 & S & $\mathrm{T}$ & $\mathrm{Z}$ \\
\hline \multirow{3}{*}{ Rubiaceae } & Cordiera concolor (Cham). Kuntze & 1 & $\mathrm{C}$ & ST & $\mathrm{Z}$ \\
\hline & Coussarea contracta (Walp.) Mull.Arg. & 59 & $\mathrm{P}$ & ST & $\mathrm{Z}$ \\
\hline & Randia ferox (Cham. \& Schltdl.) DC. & 1 & $\mathrm{P}$ & ST & $\mathrm{Z}$ \\
\hline \multirow[t]{5}{*}{ Rutaceae } & Balfourodendron riedelianum (Engl.) Engl. & 1 & S & $\mathrm{T}$ & A \\
\hline & Citrus sp. & 1 & - & $\mathrm{SH}$ & $\mathrm{Z}$ \\
\hline & Zanthoxylum fagara (L.) Sarg. & 2 & S & $\mathrm{T}$ & $\mathrm{Z}$ \\
\hline & Zanthoxylum petiolare A.St.-Hil. \& Tul & 7 & S & $\mathrm{T}$ & $\mathrm{Z}$ \\
\hline & Zanthoxylum rhoifolium Lam. & 8 & S & $\mathrm{T}$ & $\mathrm{Z}$ \\
\hline \multirow[t]{5}{*}{ Salicaceae } & Banara tomentosa Clos & 11 & S & $\mathrm{T}$ & $\mathrm{Z}$ \\
\hline & Casearia decandra Jacq. & 34 & S & $\mathrm{T}$ & $\mathrm{Z}$ \\
\hline & Casearia obliqua Spreng. & 9 & S & $\mathrm{T}$ & $\mathrm{Z}$ \\
\hline & Casearia sylvestris $\mathrm{Sw}$ & 17 & S & $\mathrm{T}$ & $\mathrm{Z}$ \\
\hline & Xylosma pseudosalzmanii Sleumer & 1 & S & $\mathrm{T}$ & $\mathrm{Z}$ \\
\hline \multirow[t]{5}{*}{ Sapindaceae } & Allophylus edulis (A.St.-Hil. et al.) Hieron. ex Niederl. & 25 & S & ST & $\mathrm{Z}$ \\
\hline & Allophylus guaraniticus (A. St.-Hil.) Radlk. & 8 & $\mathrm{C}$ & ST & $\mathrm{Z}$ \\
\hline & Cupania vernalis Cambess. & 54 & $\mathrm{P}$ & $\mathrm{T}$ & $\mathrm{Z}$ \\
\hline & Diatenopteryx sorbifolia Radlk. & 43 & $\mathrm{P}$ & $\mathrm{T}$ & $\mathrm{Z}$ \\
\hline & Matayba elaeagnoides Radlk. & 25 & S & $\mathrm{T}$ & $\mathrm{Z}$ \\
\hline \multirow[t]{2}{*}{ Sapotaceae } & Chrysophyllum gonocarpum (Mart. \& Eichler ex Miq.) Engl. & 5 & S & $\mathrm{T}$ & $\mathrm{Z}$ \\
\hline & Chrysophyllum marginatum (Hook. \& Arn.) Radlk. & 7 & S & $\mathrm{T}$ & $\mathrm{Z}$ \\
\hline Simaroubaceae & Picrasma crenata (Vell.) Engl. & 1 & S & ST & $\mathrm{Z}$ \\
\hline \multirow[t]{4}{*}{ Solanaceae } & Cestrum bracteatum Link \& Otto & 11 & S & $\mathrm{SH}$ & $\mathrm{Z}$ \\
\hline & Solanum mauritianum Scop. & 5 & S & ST & $\mathrm{Z}$ \\
\hline & Solanum pseudoquina A.St.-Hil. & 2 & $\mathrm{P}$ & ST & $\mathrm{Z}$ \\
\hline & Solanum sanctae-katharinae Dunal & 3 & $\mathrm{P}$ & ST & $\mathrm{Z}$ \\
\hline Styracaceae & Styrax leprosus Hook. \& Arn. & 3 & S & ST & $\mathrm{Z}$ \\
\hline
\end{tabular}


Table 1. Continued...

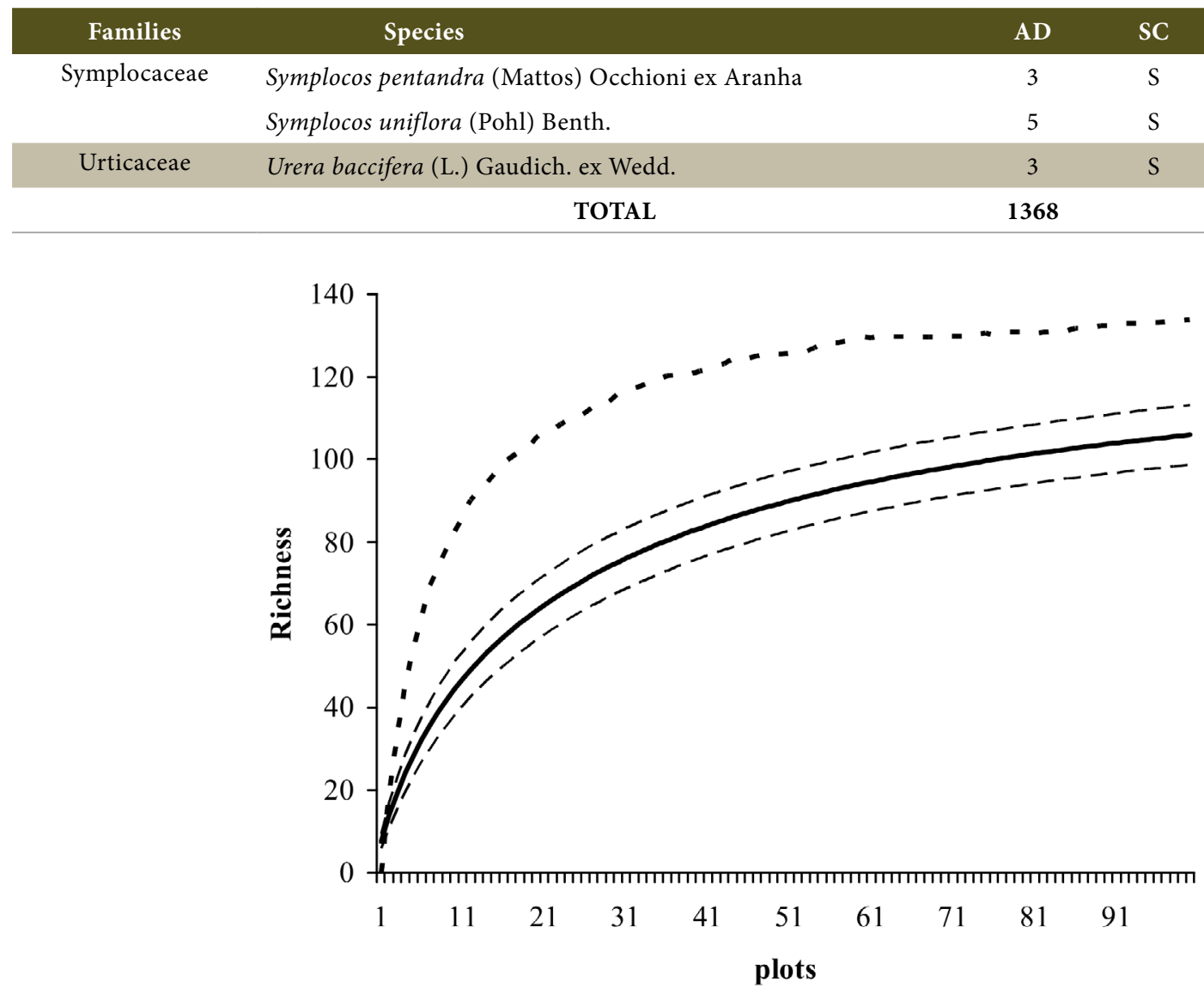

Figure 2. Observed richness (dark solid line) with a 95\% confidence interval (dashed lines) and the estimated richness by the Jackknife2 estimator (light solid line) for the tree component of the Parque Estadual das Araucárias, Santa Catarina, southern Brazil.

The families with the highest specific richness were Fabaceae (14 spp.), Lauraceae, Myrtaceae (8 spp.) and Meliaceae (7 spp.). These families, added to Rutaceae, Salicaceae, Sapindaceae and Solanaceae accounted for more than $50 \%$ (55 spp.) of the sampled species (Table 1). Except for the high specific richness of Fabaceae, this floristic pattern has been found in surveys of the MOF (Klauberg et al., 2010; Lingner et al., 2007; Martins-Ramos, et al. 2011; Seger et al., 2005). Fabaceae and Myrtaceae are considered the families with the highest specific richness in seasonal forests, while Lauraceae is mainly associated with the MOF in southern Brazil (Reitz et al., 1978). The found family composition reflects the environmental characteristics of PEAR, which involves a transition area between the MOF and the seasonal deciduous forest.

In a natural regeneration study carried out in the PEAR (Passos, 2016), A. angustifolia has showed a total natural regeneration rate of $0.1 \%$, which indicates a low potential for regeneration of the species in the area. The low regeneration of $A$. angustifolia, the high specific richness of Fabaceae and
Myrtaceae, and the proximity of the fragments to the Deciduous Seasonal Forest suggest that the forest formation in the PEAR undergoes a process of floristic change. This observation corroborates the information about the expansion of the distribution area of Mimosoideae species (Fabaceae) for the forests of the Santa Catarina plateau (Amaral et al., 2015). Maack (1981) considered the possibility of retraction of the MOF, which would be confined to areas of subtropical climate, while Klein (1978) reported a tendency of expansion of the seasonal deciduous forest on the MOF. However, Orihuela et al. (2015) have recorded that MOF and seasonal deciduous forests shared $31 \%$ of species. In this context, long-term monitoring of the PEAR forest structure can contribute to the understanding of this issue.

Of the 106 species sampled, 15\% (16 spp.) were represented by an individual and can be considered locally rare. This data highlights the importance of PEAR, as rare species are important for ecology and conservation, in addition to being frequently the focus of political decisions (Lim et al. 2012). In a Lauraceae rarity analysis carried out for the SC plateau, 
$59.4 \%$ of the species were considered rare in this region, with a high percentage of stenotopic (43.2\%) and stenoic (40.5\%) species (Fontana et al., 2016).

Compared to the results of the IFFSC (Gasper et al., 2013b), 198 species cited for the MOF were not sampled in the PEAR, which confirms the floristic heterogeneity of the MOF throughout its distribution area (Leite \& Klein, 1990). On the other hand, two species (Symplocos pentandra (Mattos) Occhioni ex Aranha and Symplocos uniflora (Pohl) Benth) mentioned for the MOF (Reitz et al., 1978), and not sampled by the IFFSC (Gasper et al., 2013b), were registered in the present study. These results prove the importance of regional floristic surveys for the knowledge of the flora of the MOF.

The five species with the highest Importance Value Index (VI) were Nectandra megapotamica, A. angustifolia, O. diospyrifolia, L. divaricata and I. paraguariensis (Table 2). The dominance of $A$. angustifolia contributes to its high value of VI. The species with the highest density were N. megapotamica, I. paraguariensis, L. divaricata, Ateleia glazioveana, and Coussarea contracta. The first three species and Ocotea diospyrifolia also presented the highest frequencies. The species with the greatest dominance were A. angustifolia, N. megapotamica, O. diospyrifolia, L. divaricata, and Ocotea puberula (Table 2). Nectandra megapotamica, the species with the highest VI, occupied different microhabitats, and can be classified from climax to pioneer in secondary vegetation (Backes \& Irgang, 2002).

Analysing studies carried out in the northern plateau of SC (Lingner et al., 2007; Negrelle \& Silva, 1992) and the results of this study, we have observed that A. angustifolia, Ilex paraguariensis, Cupania vernalis, and O. puberula were among the 10 species with the highest VI values. There has been a strong association between $A$. angustifolia, and O. porosa (Klein, 1978) for the northern plateau of SC, sharing in addition to the high VI, high density, dominance, frequency and basal area. In comparison to the studies carried out in the southern plateau of SC (Higuchi et al., 2013; Klauberg et al., 2010; Martins et al., 2012), we have observed that A. angustifolia, Dicksonia sellowiana, Cupania vernalis and Ocotea puberula were among the 10 species with the highest VI values. There is also a greater association between $A$. angustifolia with $O$. puchella and $O$. puberula for the southern plateau. However, at altitudes above $1,200 \mathrm{~m}$ in the southern plateau, Drimys angustifolia (Higuchi et al., 2013; Martins et al., 2012) and Drimys brasiliensis (Higuchi et al., 2013) have appeared among the species with the highest VI.

Table 2. Phytosociological descriptors for the 20 species with the highest importance value (VI) of the tree community sampled in the Parque Estadual das Araucárias, Santa Catarina state, southern Brazil. $\mathrm{AD}=$ absolute density, $\mathrm{RD}=$ relative density $(\%)$, AF $=$ absolute frequency $(\%), \mathrm{RF}=$ relative frequency $(\%), \mathrm{ADo}=$ absolute dominance, $\mathrm{RDo}=$ relative dominance, $\mathrm{VI}(\%)=(\mathrm{RD}+\mathrm{RF}+\mathrm{RDo}) / 3$.

\begin{tabular}{|c|c|c|c|c|c|c|c|}
\hline Species & AD & RD & AF & RF & ADo & RDo & VI (\%) \\
\hline Nectandra megapotamica & 95 & 6,94 & 46 & 6,02 & 4,197 & 8,95 & 7,31 \\
\hline Araucaria angustifolia & 31 & 2,27 & 20 & 2,62 & 6,615 & 14,11 & 6,33 \\
\hline Ocotea diospyrifolia & 56 & 4,09 & 34 & 4,45 & 2,548 & 5,43 & 4,66 \\
\hline Luehea divaricata & 59 & 4,31 & 32 & 4,19 & 2,325 & 4,96 & 4,49 \\
\hline Ilex paraguariensis & 61 & 4,46 & 30 & 3,93 & 1,615 & 3,44 & 3,94 \\
\hline Ocotea puberula & 53 & 3,87 & 19 & 2,49 & 2,062 & 4,4 & 3,59 \\
\hline Dicksonia sellowiana & 57 & 4,17 & 18 & 2,36 & 1,64 & 3,5 & 3,34 \\
\hline Prunus myrtifolia & 31 & 2,27 & 23 & 3,01 & 1,801 & 3,84 & 3,04 \\
\hline Cupania vernalis & 54 & 3,95 & 24 & 3,14 & 0,871 & 1,86 & 2,98 \\
\hline Diatenopteryx sorbifolia & 43 & 3,14 & 24 & 3,14 & 1,218 & 2,6 & 2,96 \\
\hline Alsophila setosa & 55 & 4,02 & 11 & 1,44 & 1,362 & 2,9 & 2,79 \\
\hline Ateleia glazioveana & 65 & 4,75 & 14 & 1,83 & 0,766 & 1,63 & 2,74 \\
\hline Coussarea contracta & 59 & 4,31 & 17 & 2,23 & 0,624 & 1,33 & 2,62 \\
\hline Matayba elaeagnoides & 25 & 1,83 & 20 & 2,62 & 1,345 & 2,87 & 2,44 \\
\hline Casearia decandra & 34 & 2,49 & 23 & 3,01 & 0,327 & 0,7 & 2,06 \\
\hline Parapiptadenia rigida & 25 & 1,83 & 18 & 2,36 & 0,886 & 1,89 & 2,02 \\
\hline Allophylus edulis & 25 & 1,83 & 20 & 2,62 & 0,508 & 1,08 & 1,84 \\
\hline Cordyline spectabilis & 20 & 1,46 & 15 & 1,96 & 0,893 & 1,91 & 1,78 \\
\hline Apuleia leiocarpa & 3 & 0,22 & 3 & 0,39 & 1,924 & 4,11 & 1,57 \\
\hline Cordia americana & 12 & 0,88 & 9 & 1,18 & 1,206 & 2,57 & 1,54 \\
\hline
\end{tabular}


When we compared the phytosociological results of the PEAR with the studies carried out in the northern plateau of SC, we have observed that A. angustifolia, C. vernalis, and $O$. puberula were among the main species in the structure and composition of the tree communities (Lingner et al., 2007; Negrelle \& Silva, 1992). However, when we compared with the studies of the southern plateau of SC, we have observed the relevance of $A$. angustifolia, D. sellowiana, and I. paraguariensis (Higuchi et al., 2013; Klauberg et al., 2010; Martins et al., 2012). In addition to A. angustifolia, C. vernalis is among the species with the highest VI in all regions. The differential characteristics of the PEAR tree community, representative of the western region of SC, are the association of $A$. angustifolia and N. megapotamica (both with high VI, density, dominance, frequency and basal area) and the absence of Drimys spp. and Podocarpus spp.

The total basal area was $46.88 \mathrm{~m}^{2} \mathrm{ha}^{-1}$, one of the highest values recorded for the MOF in southern Brazil (Table 3). Values greater than $35 \mathrm{~m}^{2} \mathrm{ha}^{-1}$ can be expected for conserved forests, while values close to $22 \mathrm{~m}^{2} \mathrm{ha}^{-1}$ can be expected for secondary succession phases (Longhi, 1997). Based on this criterion, it can be considered that the PEAR is in an advanced stage of ecological succession.
Shannon's diversity index was 3.96 nats ind ${ }^{-1}$, higher than those recorded in other studies (Table 3). The Pielou equability index was 0.85 nats ind $^{-1}$, which is similar to that recorded in other studies (Table 3). Despite the differences in the inclusion criteria and the area studied between some studies, it is possible to conclude that the PEAR presents a high diversity of tree species and that there is not a strong dominance of one or some species, regarding the distribution of individuals.

Individuals were sampled in all diametric classes, with a greater number of individuals from the first to the last class, which resulted in inverted J-shaped distribution (negative exponential model) (Figure 3). This distribution pattern has been observed in several studies at MOF in southern Brazil (Herrera et al., 2009; Klauberg et al., 2010; Rondon Neto et al., 2002a,b). In most species, individuals were concentrated in the diametric classes of up to $20 \mathrm{~cm}$ of DBH. Among them, we can mention A. angustifolia, which presented a multimodal distribution, which is typical of forests in which this species has been exploited (Herrera et al., 2009). However, the greater presence of individuals in the smallest diametric class does not mean that regeneration problems do not exist (Carvalho et al., 2007), and a specific study on regeneration must be performed.

Table 3. Phytosociological surveys of the tree component of mixed ombrophylous forest remnants in southern Brazil. AR - area of the studied remnant (ha); SA - sampled area (ha); CI - criterion for inclusion of individuals (diameter at breast height ( $\geq \mathrm{cm}$ ); AD: absolute density (ind ha $\left.{ }^{-1}\right)$; BA: basal area $\left(\mathrm{m}^{2} \mathrm{ha}^{-1}\right)$; $\mathrm{H}^{\prime}$ : Shannon's diversity index; J: Pielou's equability index.

\begin{tabular}{lccccccc} 
& AR & SA & CI & AD & BA & H' & J \\
\hline Nascimento et al. (2001) & 720 & 1 & 9,6 & 848 & - & 3,00 & - \\
\hline Rondon Neto et al. (2002a) & 6,75 & 0,8 & 5,0 & 841 & 45,01 & 2,77 & - \\
\hline Rondon Neto et al. (2002b) & 15,24 & 0,36 & 5,0 & 1.972 & 37,08 & 3,44 & - \\
\hline Cordeiro; Rodrigues (2007) & 104 & 0,32 & 4,8 & 1.397 & - & 2,79 & 0,90 \\
\hline Herrera et al. (2009) & 1.194 & 2,6 & 10 & 484 & 31,4 & 3,59 & - \\
Klauberg et al. (2010) & 234,42 & 0,64 & 5,0 & 1.150 & 34,2 & 3,05 & 0,81 \\
\hline Martins et al. (2012) & $1.367,43$ & 0,58 & 5,0 & 1.672 & 39,58 & 2,6 & 0,88 \\
Higuchi et al. (2012) & 103,06 & 1 & 5,0 & 1.843 & 36,45 & 3,74 & 0,83 \\
\hline Higuchi et al. (2013) & 48,91 & 1 & 5,0 & 1.395 & 34,80 & 2,79 & 0,70 \\
Present study & 612 & 1 & 5,0 & 1.368 & 46,88 & 3,96 & 0,85
\end{tabular}

Secondary species ( $63 \%$ of species) are the majority in the area, followed by pioneers $(24 \%)$, climax $(9 \%)$ and unclassified species (4\%). The predominance of secondary and pioneer species is related to the history of the use of the area. Some areas of the PEAR are covered by grasses interspersed with yerba mate (Ilex paraguariensis) and in some areas, inside the forest, a massive presence of bamboo (Merostachys multiramea) occurred (personal observation). The bamboo may be the cause of the reduction in the regeneration of the dominant tree species in the understory of the MOF
(Sanquetta et al., 2005). Thus, in the most disturbed areas of the PEAR, pioneer species, such as Ateleia glazioveana and Merostachys multiramea, predominated. However, in the most conserved areas, climax species of Myrtaceae and Lauraceae were observed, in addition to Dicksonia sellowiana (personal observation). Regarding the dispersal syndrome, $70.7 \%$ (74) of the species are zoochorous, $27.3 \%$ (29) anemochorous and 2\% (3) autochorous. Dispersal by animals is expected for the MOF (Klauberg et al., 2010). According to Mikich \& Silva (2001), vegetation complexity 
increases in forests in more advanced successional stages attracting birds and mammals. Therefore, we must conserve the fauna in these forests for processes such as pollination, dispersal and regeneration to occur.

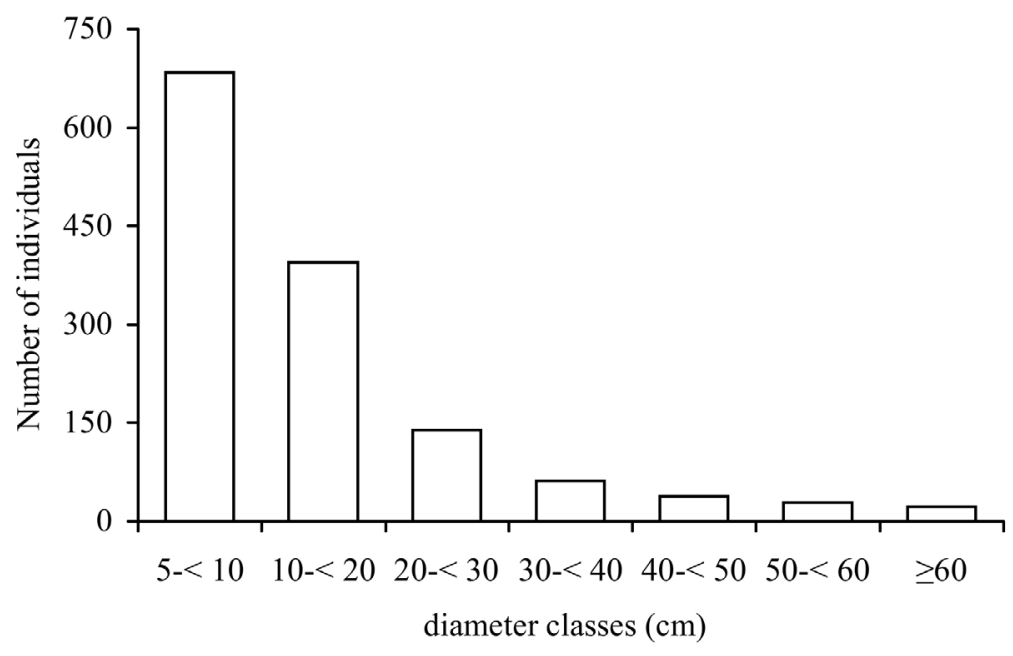

Figure 3. Number of individuals by diameter classes in a mixed ombrophylous forest remnant in southern Brazil.

Preliminary data from the PEAR Management Plan indicate the occurrence of 281 species of birds and 31 small and medium-sized mammals (FATMA, 2015). However, some factors can negatively affect the regeneration process of tree species. Alves (2008) has observed a high population density of Sapajus nigritus Goldfuss, 1809 (capuchin monkey) in the PEAR. Researchers and park rangers observed in situ (personal communication) S. nigritus feeding on shoots of Syagrus romanzoffiana or on the bark of young plants of $A$. angustifolia, which can result in the death of individuals. There are also reports of early extraction of pine cones in the PEAR, which can affect the regeneration of $A$. angustifolia.

Among the species sampled in the PEAR, many of them are on the list of vulnerable and threatened species. According to the Ministry of the Environment (MMA, 2014), A. angustifolia, Diksonia sellowiana and Ocotea porosa are classified as at risk of extinction, while Apuleia leiocarpa is classified as vulnerable. According to the list of the International Union for Conservation of Nature (IUCN, 2015), in addition to the species mentioned, Cedrela odorata (vulnerable), Balfourodendron riedelianum, Cedrela fissilis and Cedrela lilloi (endangered) are also included.

\section{CONCLUSION}

Despite past anthropogenic disturbances, the diversity of tree species is high (106 species per hectare), and there is an intrinsic association between A. angustifolia and N. megapotamica. The analysis of the data has indicated a predominance of secondary tree species, as the PEAR presents forest patches in several successional stages. More than 70\% of the sampled species were zoochorous, demonstrating the fragment's importance for maintaining the region's fauna diversity. We also highlight the importance of PEAR for hosting endangered and vulnerable species of Santa Catarina flora. Therefore, PEAR can act as a reference for MOF restoration projects in western Santa Catarina, and as a source of propagules for species.

\section{ACKNOWLEDGEMENTS}

We thank Fundação de Amparo a Pesquisa no Estado de Santa Catarina (FAPESC); National Science Foundation and São Paulo State Research Support Foundation for the postdoctoral fellowship (NSF-FAPESP PIRE-CREATE project grants 2017/50085-3 and 2019/27110-7); This study was financed in part by the Coordenação de Aperfeiçoamento de Pessoal de Nível Superior (CAPES)-Brazil-Finance Code 001.

\section{SUBMISSION STATUS}

Received: 22 Jul. 2020

Accepted: 01 Dec. 2020

Associate editor: Rodrigo Studart Corrêa (1)

\section{CORRESPONDENCE TO}

Manuela Gazzoni dos Passos

Universidade Estadual de Londrina, Centro de Ciências Biológicas, Rodovia Celso Garcia Cid, PR-445, Km 380, Campus Universitário, CEP 86057-970, Londrina, PR, Brasil e-mail: biologamanu@gmail.com 


\section{REFERENCES}

Amaral GM, Fontana C, Gasper AL, Freitas DS, Sevegnani L. Aspectos da distribuição de Mimosoideae (Fabaceae) arbóreas no planalto de Santa Catarina, sul do Brasil. Neotropical Biology and Conservation 2015; 10(2):74-84.

Alvares CA, Stape J L, Sentelhas PC, Gonçalves JLM, Sparovek G. Köppen's climate classification map for Brazil. Meteorologische Zeitschrift 2013; 22:711-728.

Alves FC. Estudo populacional de Cebus nigritus (Goldfuss, 1809) no Parque Estadual das Araucárias - São Domingos, Santa Catarina [dissertação]. Chapecó: Universidade Comunitária Regional de Chapecó; 2008.

APG IV. An update of the Angiosperm Phylogeny Group classification for the orders and families of flowering plants. Botanical Journal of the Linnean Society 2016; 181(1):1 - 20.

Backes P, Irgang B. Árvores do Sul: guia de identificação e interesse ecológico. Santa Cruz do Sul: Instituto Souza Cruz; 2002.

Brasil. Lei $n^{\circ} 12.651 / 2012$, que dispõe sobre o Novo código Florestal. Disponível em: <http://www.planalto.gov.br/ccivil_03/_ato20112014/2012/lei/112651.htm>. Acesso em: 15 jul. 2018.

Carvalho FA, Nascimento MT, Braga JMA. Estrutura e composicao floristica do estrato arboreo de um remanescente de Mata Atlantica no municipio de Rio Bonito, RJ, Brasil (Mata Rio Vermelho). Revista Arvore 2007; 31(4):717-730.

Carvalho MMX. Os fatores do desmatamento da Floresta com Araucária: agropecuária, lenha e indústria madeireira. Esboços 2012; 18(25):32-52.

Carvalho PER. Espécies arbóreas brasileiras. v.2. Brasília: Embrapa Informação Tecnológica; 2006.

Cientec. Mata Nativa 2: manual do usuário. Viçosa: Cientec; 2006.

Colwell, RK. EstimateS: statistical estimation of species richness and shared species from samples. Version 9.1.0. 2013. Disponível em: <http://viceroy.eeb.uconn.edu/estimates $>$. Acesso em 06/2016.

Cordeiro J, Rodrigues WA. Caracterização fitossociológica de um remanescente de Floresta Ombrófila Mista em Guarapuava, PR. Revista Árvore 2007; 31(3):545-554.

Dajoz R. Ecologia Geral. 4. ed. Petrópolis: Editora Vozes; 1983.

Dallabrida JP, Cruz AP, Souza CC, Alves M, Soboleski VDF, Loebens $\mathrm{R}$, et al. Tree component demography in an upper montane mixed ombrophilous forest under chronic anthropogenic disturbances. Revista Árvore 2018; 41(3):e410312. http://dx .doi.org/ 10.1590/1806-90882017000300012

FATMA - Fundação de Meio Ambiente. Plano de Manejo - Fase II - Parque Estadual das Araucárias: $1^{a}$ versão do plano revisado. Florianópolis: Apremavi; 2015.

Fontana C, Gasper A, Sevegnani L. A raridade das espécies arbóreas de Lauraceae no planalto do Estado de Santa Catarina, Brasil. Hoehnea 2016; 43(3):361-369.

Formento S, Schorn LA, Ramos RABR. Dinâmica estrutural arbórea de uma floresta ombrófila mista em Campo Belo do Sul, SC. Cerne 2004; 10:196-212.
FGV - Fundação Getúlio Vargas. Financiamento da Recomposição Florestal com Exploração Econômica da Reserva Legal. Disponível em: <http:/gvces.com.br/financiamento-da-recomposicao-florestalcom-exploracao-economica-da-reserva-legal?locale=pt-br $>$. Acesso em: 15 jul. 2018.

Gasper AL, Sevegnani L, Sobral MG, Meyer L, Verdi M, Santos AS, et al. Flora vascular da Floresta Ombrófila Mista em Santa Catarina. In: Vibrans AC, Sevegnani L, Gasper AL, Lingner DV, editors. Inventário florístico florestal de Santa Catarina: Floresta Ombrófila Mista. v. 3. Blumenau: Edifurb; 2013b. p. 131-141.

Gasper AL, Uhlmann A, Sevegnani L, Lingner DV, Rigon-Júnior MJ, Verdi M, et al. Inventário florístico florestal de Santa Catarina: espécies da Floresta Ombrófila Mista. Rodriguésia 2013a; 64(2):201-210.

Herrera HAR, Rosot NC, Rosot MAD, Oliveira YMM. Análise florística e fitossociológica do componente arbóreo da Floresta Ombrófila Mista presente na Reserva Florestal Embrapa/Epagri, Caçador, SC - Brasil. Floresta 2009; 39(3):485-500.

Higuchi P, Silva AC, Almeida JA, Bortoluzzi RLC, Mantovani A, Ferreira TS, et al. Florística e estrutura do componente arbóreo e análise ambiental de um fragmento de floresta ombrófila mista alto-montanha no município de Painel, SC. Ciência Florestal 2013; 23(1):153-164.

Higuchi P, Silva AC, Ferreira TS, Souza ST, Gomes JP, Silva KM, Santos KF. Floristic composition and phytogeography of the tree component of Araucaria Forest fragments in southern Brazil. Brazilian Journal of Botany 2012; 35(2):145-157.

IBGE - Instituto Brasileiro de Geografia e Estatística. Manual técnico da vegetação brasileira. 2. ed. Rio de Janeiro: Coordenação de Recursos Naturais e Estudos Ambientais; 2012.

IUCN - International Union for Conservation of Nature. The IUCN red list of threatened species. Version 2015.2. Disponível em: http://www.iucnredlist.org. Acesso em: 03 de janeiro, 2016.

Klauberg C, Paludo GF, Bortoluzzi RLC, Mantovani A. Florística e estrutura de um fragmento de Floresta Ombrófila Mista no Planalto Catarinense. Biotemas 2010; 23(1):35-47.

Klein RM. Mapa fitogeográfico do estado de Santa Catarina. In: Reitz R, editor. Flora Ilustrada Catarinense. Itajaí: Herbário Barbosa Rodrigues; 1978.

Klein RM. O aspecto dinâmico do pinheiro brasileiro. Sellowia 1960; 12(12):17-51.

Leite PF, Klein RM. Geografia do Brasil. Rio de Janeiro: IBGE; 1990.

Lim GS, Balke M, Meier R. Determining species boundaries in a world full of rarity: singletons, species delimitation methods. Systematic Biology 2012; 1:165-169.

Lingner DV, Oliveira YMM, Rosot NC, Dlugosz LF. Caracterização da estrutura e da dinâmica de um remanescente de Floresta com Araucária no Planalto Catarinense. Pesquisa Florestal Brasileira 2007; 55(1):55-66.

Longhi S. Agrupamento e análise fitossociológica de comunidades florestais na sub-bacia hidrográfica do rio Passo Fundo-RS [Thesis]. Curitiba: Setor de Ciências Agrárias, Universidade Federal do Paraná; 1997.

Lorenzi H. Árvores brasileiras: manual de identificação e cultivo de plantas arbóreas nativas do Brasil. v.1, 5. ed. Nova Odessa: Instituto Plantarum; 2008.

Ludwig JA, Reynolds JF. Statistical Ecology. New York: John Wiley \& Sons; 1988. 
Maack R. Geografia física do Estado do Paraná. 1. ed . Curitiba: J. Olympio; 1981.

Manfredi S, Gomes JP, Ferreira PI, Bortoluzzi RLC, Mantovani A. Dissimilaridade florística e espécies indicadoras de floresta ombrófila mista e ecótonos no planalto sul Catarinense. Floresta 2015; 45(3):497-506.

Martins D, Rodrigues AL, Chaves CL, Mantovani A, Bortoluzii RLC. Estrutura de um remanescente de Floresta Ombrófila Mista em Urupema, Santa Catarina, Brasil. Revista de Ciências Agroveterinárias 2012; 11(2):126-137.

Martins-Ramos D, Chaves CL, Bortoluzzi RLC, Mantovani A. Florística de Floresta Ombrófila Mista Altomontana e de Campos em Urupema, Santa Catarina, Brasil. Revista Brasileira de Biociências 2011; 9(2):156-166.

Meyer L, Gasper AL, Sevegnani L, Schorn LA, Vibrans AC, Lingner DV, et al. Regeneração natural da Floresta Ombrófila Mista em Santa Catarina. In: Vibrans AC, Sevegnani L, Gasper AL, Lingner DV, editors. Inventário florístico florestal de Santa Catarina: Floresta Ombrófila Mista. v. 3. Blumenau: Edifurb; 2013. p.191-222.

Mikich SB, Silva SM. Composição florística e fenologia das espécies zoocóricas de remanescentes de Floresta Estacional Semidecidual no centro-oeste do Paraná, Brasil. Acta Botanica Brasilica 2001; 5(1):89-113.

MMA - Ministério do Meio Ambiente. Espécies da flora brasileira ameaçadas de extinção. Portaria MMA nº 443, de 17 de dezembro de 2014.

Mueller-Dombois D, Ellenberg H. Aims and methods of vegetation ecology. New York: John Wiley \& Sons; 1974.

Negrelle RAB, Silva FC. Fitossociologia de um trecho de Floresta com Araucaria angustifolia (Bert.) O. Ktze. no município de Caçador-SC. Boletim de Pesquisa Florestal 1992; 24/25:37-54. https:/www.alice. cnptia.embrapa.br/bitstream/doc/282129/1/rnegrelle.pdf

Oliveira LZ, Moser P, Vibrans AC, Piazza GA, Gasper AL, Oliveira Filho AT. Insights for selecting the most suitable nonparametric species-richness estimators for subtropical Brazilian Atlantic Forests. Revista Brasileira de Botânica 2016; 39(2):593-603.

Orihuela RLL, Peres CA, Mendes G, Jarenkow JA, Tabarelli M. Markedly divergent tree assemblage responses to tropical forest loss and fragmentation across a strong seasonality gradient. PLoS ONE 2015; 10(8):e0136018. doi:10.1371/journal.pone.0136018

Passos MG. Estrutura florestal e regeneração natural do Parque Estadual das Araucárias, SC [Thesis]. Londrina: Universidade Estadual de Londrina; 2016,
Reitz R, Klein RM, Reis A. Projeto madeira de Santa Catarina: levantamento das espécies florestais nativas em Santa Catarina com a possibilidade de incremento e desenvolvimento. Itajaí: Sudesul; 1978.

Reitz PR. Plano de coleção. Flora Ilustrada Catarinense 1965; IV(A):1-75.

Rondon Neto RM, Watzlawick LF, Caldeira MVW, Shoeninger ER. Análise florística e estrutural de um fragmento de Floresta Ombrófila Mista Montana, situado em Criúva - RS, Brasil. Ciência Florestal 2002a; 12(1):29-37.

Rondon Neto R, Kozera C, Andrade RR, Cecy AT, Hummes AP, Fritzsons E, et al. Caracterização florística e estrutural de um fragmento de Floresta Ombrófila Mista, em Curitiba, PR - Brasil. Floresta 2002b; 32(1):3-16.

Santos GN, Higuchi P, Silva AC, Farias KJ, Machado FD, Duarte E, et al. Regeneração natural em uma Floresta com Araucária: inferências sobre o processo de construção da comunidade de espécies arbóreas. Ciência Florestal 2018; 28(2):483-494.

Sanquetta CR, Dalla Corte AP, Vulcanis L, Berni DM, Biscaia AG. Estabelecimento de plântulas de espécies arbóreas em um experimento de controle de taquaras (Bambusoideae) no sul do Paraná, Brasil. Floresta 2005; 35(1):163-177.

Santa Catarina. Números de Santa Catarina. Florianópolis: Gaplan; 1986.

Sevegnani L, Silva TC, Gasper AL, Meyer L, Verdi M. Flora arbórea e o impacto humano nos fragmentos florestais na bacia do Rio Pelotas, Santa Catarina, Brasil. Revista de Estudos Ambientais 2012; 14(1):60-73.

Shaw TE. Species diversity in restoration plantings: Important factors for increasing the diversity of threatened tree species in the restoration of the Araucaria forest ecosystem. Plant Diversity $2019 ; 41: 84-93$.

Silva JO, Silva AC, Higuchi P, Mafra ÁL, Loebens R, Carlos L, et al. Heterogeneidade ambiental e regeneração natural em uma Floresta Ombrófila Mista Aluvial. Scientia Forestalis 2016; 44(112):787-797.

Van der Pijl L. Principles of dispersal in higher plants. 3 ed. Berlin: Springer-Verlag; 1982.

Vibrans AC, McRoberts RE, Lingner DV, Nicoletti AL, Moser P. Extensão original e remanescentes florestais da Floresta Ombrófila Mista em Santa Catarina. In: Vibrans AC, Sevegnani L, Gasper AL, Lingner DV, editors. Inventário florístico florestal de Santa Catarina: Floresta Ombrófila Mista. v. 3. Blumenau: Edifurb; 2013. p.25-32.

Vibrans AC, Sevegnani L, Lingner DV, Gasper AL, Sabbagh S. O Inventário Florístico Florestal de Santa Catarina (IFFSC). Pesquisa Florestal Brasileira 2010; 30(64):291-302. 